\title{
Harnessing $\mathrm{CD}^{+} \mathrm{CD}^{-} 8^{-}$Regulatory $\mathrm{T}$ Cells as a Tool to Treat Autoimmune Disease
}

\author{
Sabrina Ceeraz ${ }^{1}$, Charlotte R. Thompson ${ }^{2}$, Richard Beatson ${ }^{3}(1)$ and Ernest H. Choy ${ }^{4, *}$ \\ 1 Carisma Therapeutics, Philadelphia, PA 19104, USA; sabrina.delong@carismatx.com \\ 2 Brighton and Sussex Medical School, University of Sussex, Brighton BN1 9RH, UK; c.thompson2@bsms.ac.uk \\ 3 School of Cancer \& Pharmaceutical Sciences, Faculty of Life Sciences and Medicine, King's College London, \\ London SE1 9RT, UK; richard.1.beatson@kcl.ac.uk \\ 4 CREATE Centre, Division of Infection and Immunity, School of Medicine, \\ Cardiff University, Cardiff CF14 4XN, UK \\ * Correspondence: ChoyEH@Cardiff.ac.uk; Tel.: +44-(0)29-2068-7092
}

Citation: Ceeraz, S.; Thompson, C.R.; Beatson, R.; Choy, E.H. Harnessing $\mathrm{CD} 8^{+} \mathrm{CD} 28^{-}$Regulatory T Cells as a Tool to Treat Autoimmune Disease. Cells 2021, 10, 2973. https://doi.org/ 10.3390/cells10112973

Academic Editor: Alessandro Poggi

Received: 27 September 2021

Accepted: 28 October 2021

Published: 1 November 2021

Publisher's Note: MDPI stays neutral with regard to jurisdictional claims in published maps and institutional affiliations.

Copyright: (c) 2021 by the authors. Licensee MDPI, Basel, Switzerland. This article is an open access article distributed under the terms and conditions of the Creative Commons Attribution (CC BY) license (https:/ / creativecommons.org/licenses/by/ $4.0 /)$.

\begin{abstract}
T regulatory cell therapy presents a novel therapeutic strategy for patients with autoimmune diseases or who are undergoing transplantation. At present, the CD4 ${ }^{+}$Treg population has been extensively characterized, as a result of defined phenotypic and functional readouts. In this review article, we discuss the development and biology of $\mathrm{CD}^{+}$Tregs and their role in murine and human disease indications. A subset of $\mathrm{CD} 8^{+}$Tregs that lack the surface expression of CD28 $\left(\mathrm{CD} 8^{+} \mathrm{CD} 28^{-}\right.$Treg) has proved efficacious in preclinical models. $\mathrm{CD} 8^{+} \mathrm{CD} 28^{-}$Tregs are present in healthy individuals, but their impaired functionality in disease renders them less effective in mediating immunosuppression. We primarily focus on harnessing CD8 ${ }^{+}$Treg cell therapy in the clinic to support current treatment for patients with autoimmune or inflammatory conditions.
\end{abstract}

Keywords: CD8; Treg; autoimmunity; immunoregulation

\section{Introduction}

The immune system is a comprehensive network of multifaceted cells that exert an array of systemic and tissue-dependent functionalities. Pro- and anti-inflammatory responses are required to initiate an effector response against infections or cancers while maintaining tolerance to self-antigens and driving tissue repair. Several mechanisms play a key role in maintaining immune tolerance such as immunosuppressive cytokines, a high threshold for $\mathrm{T}$ cell activation and T regulatory cells (Tregs).

In the 1970s, Gershon and Kondo showed that T cells expressing Lyt2 (CD8 $\alpha$ ) could mediate suppressor activity, with others subsequently confirming the suppression of antigen specific responses $[1,2]$. However, a lack of tools and markers needed to identify suppressor function, compounded by the strong association of $\mathrm{CD}^{+} \mathrm{T}$ cells with cytolytic (CTL) function, led to dormancy in the field of $\mathrm{CD}^{+}$suppressor cells. In the mid-1990s, the emergence of $\mathrm{CD}^{+}$Tregs expressing the robust marker forkhead/winged helix transcription factor (Foxp3) [3-5] and association between Foxp3 gene mutations and fatal X-linked syndrome [6,7] revived interest in suppressor/regulatory cells. Our understanding of $\mathrm{CD}^{+}$Tregs has evolved to include a relatively small set of phenotypic and functional markers such as the expression of Foxp3, CD127 $7^{-} /$low and helios and inhibitory cytokine production: IL-10, IL-35 and transforming growth factor beta (TGF- $\beta 1$ ). In contrast, a vast array of markers and functions have been reported for $\mathrm{CD}^{+}$suppressor cells (now referred to as $\mathrm{CD}^{+}$Tregs) in mouse and human studies. The aim of this review is to discuss the renewed interest in the $\mathrm{CD} 8^{+} \mathrm{CD} 28^{-}$Treg subset, as a result of improved phenotypic markers, preclinical studies and detection in patients with autoimmune and inflammatory conditions. 


\section{Origin of $\mathrm{CD}^{+}$Tregs}

To date there have been no reports of $\mathrm{CD} 8^{+}$natural Tregs. Like CD4 $4^{+}$Tregs, continuous antigen stimulation of $\mathrm{CD} 8{ }^{+} \mathrm{CD} 25^{-} \mathrm{T}$ cells results in the generation of $\mathrm{CD} 8^{+} \mathrm{Foxp} 3^{+}$Tregs in response to Staphylococcus enterotoxin B [8]. In vitro, co-culture of $\mathrm{CD} 8^{+} \mathrm{CD} 28^{-} \mathrm{T}$ cells with monocytes is shown to generate suppressor cells that require IL-10 to inhibit CTL function and T cell proliferation [9]. Similarly, others have shown in vitro studies that CD3-stimulated co-cultures of bone-marrow-derived stromal cells with $\mathrm{CD} 8^{+} \mathrm{T}$ cells result in human CD8 ${ }^{+}$Tregs that express CD25, CD28 and Foxp3 [10].

$\mathrm{CD}^{+}$Tregs develop naturally or can be induced by T cell receptor (TCR) or non-TCR signals [11], mediating suppression by cell contact, cytokine and chemokine production, MHC class 1 restriction, cytotoxicity or indoleamine 2, 3-dioxygenase (IDO) production [11]. In pregnancy, human placental trophoblasts can activate CD8 ${ }^{+}$Tregs [12] and, in the eye, ocular pigment epithelial cells can covert $\mathrm{CD} 8^{+} \mathrm{T}$ cells to $\mathrm{CD} 8^{+} \mathrm{CD} 25^{+} \mathrm{Foxp}^{+}{ }^{+}$Tregs [13]. This demonstrates that $\mathrm{CD}^{+}$Tregs can mediate suppression in immune privilege sites.

CD28 loss is associated with chronic antigen stimulation [14], and, pertinent to chronic inflammatory disease, TNF- $\alpha$ has been highlighted in driving down expression in an autocrine or paracrine fashion [15]. As such, CD28 loss is considered a marker for both the generation of effector memory and terminal effector memory CD45RA ${ }^{+}$(TEMRA) subsets, and $\mathrm{CD} 8^{+}$Tregs.

\section{3. $\mathrm{CD}^{+}$Treg Populations in Mice and Humans}

Similarities between $\mathrm{CD} 4^{+} \mathrm{CD} 25^{+}$Tregs and $\mathrm{CD} 8^{+} \mathrm{CD} 122^{+}$Tregs include the ability to suppress $\mathrm{T}$ cell activity and contribute to $\mathrm{T}$ cell homeostasis [16]. CD8 ${ }^{+} \mathrm{CD} 122^{+}$Tregs are naturally occurring and resemble a memory phenotype. In mice, IL-10 producing $\mathrm{CD}^{+} \mathrm{CD} 122^{+}$Tregs mediate the suppression of activated T cells via MHC class I $\alpha \beta$ TCR signaling rather than recognition by MHC class II (I-A) and MHC class Ib molecule Qa-1 [17].

The negative checkpoint regulator (NCR) programmed death-1 (PD-1) receptor is critical for $\mathrm{CD}^{+} \mathrm{T}$ cell homeostasis, exhaustion and response to viral infections. In a murine cardiac transplantation model, inducible co-stimulator (ICOS)-B7h blockade induces alloantigen $\mathrm{CD} 8^{+} \mathrm{CD} 122^{+}$Tregs expressing PD-1, which contribute to prolonging allograft survival via a Th2 response [18]. In addition, $\mathrm{CD} 8^{+} \mathrm{CD} 122^{+}$Treg function has been reported in murine anti-tumor responses against the murine mouse lymphoblastic lymphoma cell line (EL4) and in B16-OVA and CT26 [19,20]. In humans, the equivalent of $\mathrm{CD}^{+} \mathrm{CD} 122^{+}$Tregs are $\mathrm{CD}^{+} \mathrm{CXCR}^{+} \mathrm{T}$ cells, which are distinct from central memory cells [21]. In humans and mice, $\mathrm{CD}^{+} \mathrm{Foxp}^{+}$Tregs have been reported. In humans, CD8 ${ }^{+}$Foxp $^{+}$Tregs are detected in some patients with rheumatoid arthritis (RA) [22], systemic lupus erythematosus (SLE) [23], Epstein-Barr virus (EBV) infections [24], patients with prostate cancer [25] and allogeneic stem cell transplantation [26]. In mice CD8 ${ }^{+}$Tregs expressing Foxp3 are reported in lupus-prone mice [27], allogeneic stem cell [26] and bone marrow transplantation [28].

Recent studies have identified suppressive $\mathrm{CD} 8^{+} \mathrm{CD} 103^{+}$Tregs that express $\mathrm{CD} 39$ that inhibit lupus nephritis in a graft-versus-host disease (GvHD) model [27] or alloprimed $\mathrm{CD}^{+} \mathrm{T}$ cells expressing CXCR5 suppress post-transplant alloantibody production [29]. $\mathrm{CD}^{+} \mathrm{T}$ cells that lack surface expression of $\mathrm{CD} 28\left(\mathrm{CD} 8^{+} \mathrm{CD} 28^{-}\right.$Treg) have been widely documented in autoimmune diseases and inflammatory conditions [30-32]. We have previously shown that, in RA patients, $\mathrm{CD} 8^{+} \mathrm{CD} 28^{-}$Tregs are dysfunctional due to defective suppressor function and/or the reduced responsiveness of target cells to suppression, which can be corrected by anti-TNF therapy [33]. CD8 ${ }^{+}$Treg markers in mice and humans are summarized in Figure 1. 


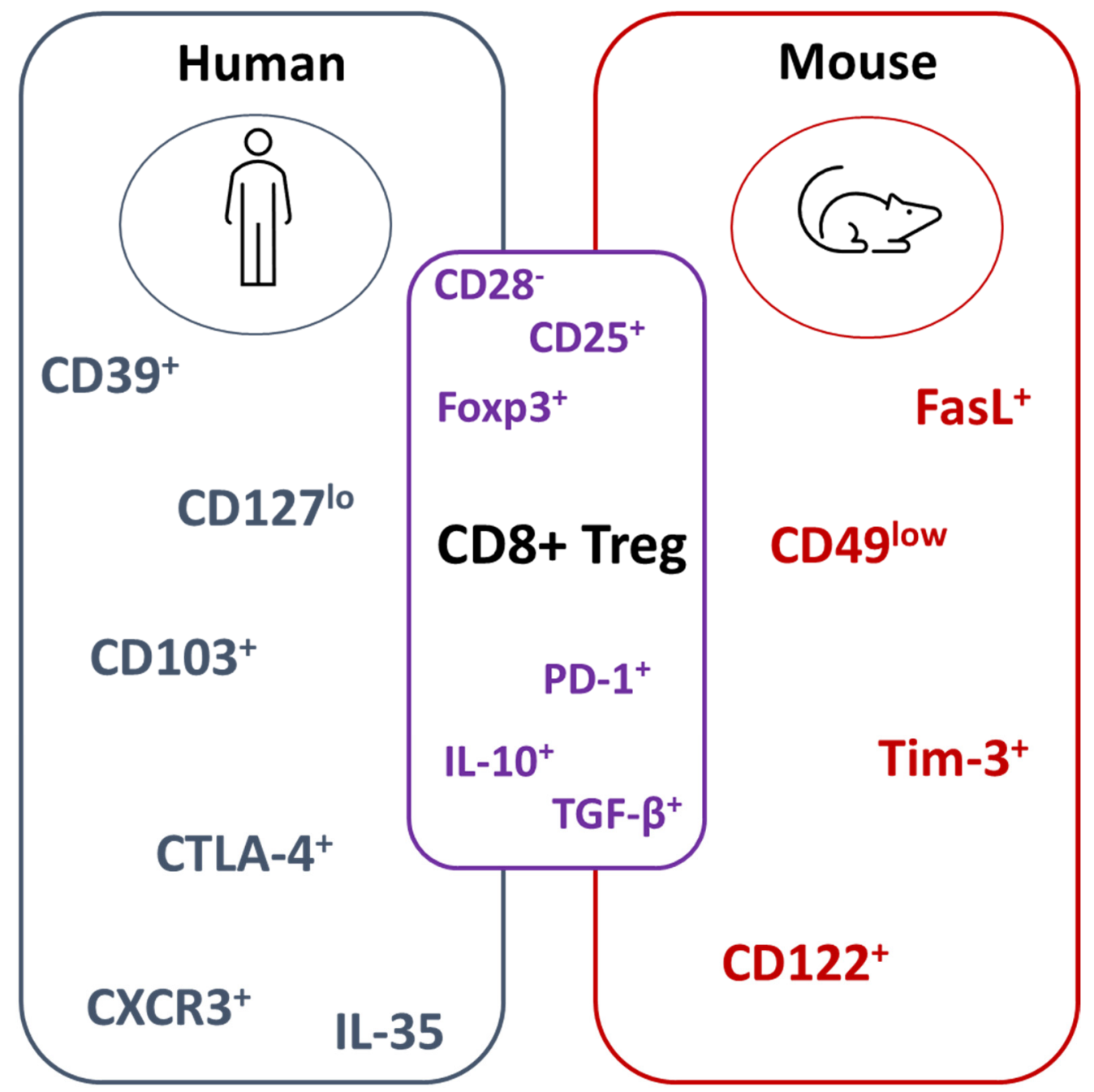

Figure 1. Summary of $\mathrm{CD} 8^{+}$Treg markers in mice and humans. $\mathrm{CD} 8^{+}$Treg phenotypic and functional markers differ between human and mouse studies. Well-characterized molecules between both species include the absence of CD28 and the expression of Foxp3. For functional readouts, IL-10 and TGF- $\beta 1$ has been reported. Cytotoxic T-lymphocyte-associated protein 4 (CTLA-4); programmed death-1 (PD-1); T-cell immunoglobulin and mucin domain 3 (Tim-3); transforming growth factor beta (TGF- $\beta$ ).

\section{Mechanisms of Suppression Mediated by $\mathrm{CD}^{+}$Tregs}

The ability of $\mathrm{CD}^{+}$Tregs to suppress inflammation is partly mediated by targeting autoreactive or alloantigens, as well as conventional $\mathrm{CD}^{+} \mathrm{T}$ cells. Several studies have demonstrated that $\mathrm{CD}^{+}$Tregs suppress activated antigen-specific $\mathrm{CD} 4^{+} \mathrm{T}$ cells expressing Qa-1 [34]. As Qa-1 binds self-peptides that activate natural killer (NK) receptors on CD8 ${ }^{+}$ $\mathrm{T}$ cells, Qa-1 may play a critical role in $\mathrm{CD}^{+}$Treg homeostasis [34].

In addition to suppressing $\mathrm{T}$ cell proliferation, there is now increasing evidence that $\mathrm{CD}^{+}$Tregs impact the B cell compartment. One mechanism is the inhibition of $\mathrm{T}$ follicular helper (Tfh) cells that highly express Qa-1 resulting in a reduction in germinal center (GC) formation, antibody-switching and maturation [35]. In ApoE mice crossed with Qa- $1^{\circ}$ mice or Qa-1 D227K mice, defective $\mathrm{CD}^{+}$Treg function accelerates atherosclerosis due to enhanced Tfh and GC function [36].

Alternative mechanisms reported for $\mathrm{CD}^{+}$Treg suppression include apoptosis [37] and the expression of TNFR2 or PD-L1 [38]. A recent study has shown that the transcription factor (TF) STAT4 may play an intrinsic role in $\mathrm{CD}^{+}$Tregs. This is demonstrated in vivo by the adoptive transfer of Stat4-deficient CD8 ${ }^{+}$Tregs into C57BL/6 (CD45.1 ${ }^{+}$) 
mice immunized with KLH/CFA, reducing Tfh cells and GC B cell formation. Similarly, in a murine atherosclerosis model, the adoptive transfer of Stat4 ${ }^{-/}-\mathrm{Ldlr}^{-/}-\mathrm{CD} 8^{+} \mathrm{CD} 122^{+}$ Tregs into $L d l r^{-/-}$recipients suppressed plaque formation, GC B cells, Tfh cells and Ig formation [39]. Under Treg skewing conditions, the polarization of splenic Stat4 ${ }^{-/-} \mathrm{CD}^{+}$ T cells to $\mathrm{CD}^{+}$Tregs is increased in vitro, and Stat $4^{-/-}$macrophages inhibit Tfh cells but enable $\mathrm{CD}^{+}$Treg differentiation. In contrast, Stat5 deficiency in the $\mathrm{CD}^{+} \mathrm{T}$ cell compartment is linked to impaired B cell tolerance due to an increase in CD8 ${ }^{+} \mathrm{Tfh}^{\mathrm{f}}$, resulting in increased autoantibody production [40]. These findings suggest TFs can serve as tool in studying $\mathrm{CD}^{+}$Treg populations and their differentiation $[39,40]$.

\section{5. $\mathrm{CD}^{+} \mathrm{CD}^{-} 8^{-}$Tregs}

$\mathrm{CD}^{+} \mathrm{CD} 28^{-}$Treg suppressor function has been reported in normal healthy individuals [41] and patients with cancer [42], those who are undergoing transplantation (rejection free recipients) [43-45] or who have gastrointestinal [46] or autoimmune [31] conditions. $\mathrm{CD}^{+} \mathrm{CD} 28^{-}$Treg generation by either allogeneic stimulator cells [47], antigen-presenting cells (APC) [48] or xenogeneic stimulator cells [47] has complicated the understanding of how these cells mediate suppression.

Overlapping markers between $\mathrm{CD} 8^{+} \mathrm{CD} 28^{-}$Tregs and $\mathrm{CD} 4{ }^{+} \mathrm{CD} 25^{+}$Tregs include the expression of Foxp3, CD25 and members of the TNF receptor family (e.g., 4-1BB) [49]. A unique feature mediated by $\mathrm{CD} 8^{+} \mathrm{CD} 28^{-}$Tregs is their ability to render APCs tolerogenic by reducing CD86 gene transcription [50] while also upregulating inhibitory receptors, such as immunoglobulin-like transcript (ILT) 3 (ILT3) and ILT4 [51].

To date, no studies have robustly characterized the molecular pathways involved in the generation and activation of $\mathrm{CD}^{+} \mathrm{CD} 28^{-}$Tregs; however, mixed lymphocyte culture (MLC) stimulation in the presence of IL-2, IL-7 and IL-15 has shown promise in generating and expanding these cells [52]. These data in combination with those described above are suggestive of JAK-STAT involvement.

\section{6. $\mathrm{CD}^{+} \mathrm{CD}^{-} 8^{-}$Tregs in Autoimmunity}

\subsection{Multiple Sclerosis}

In experimental autoimmune encephalomyelitis (EAE), the murine model of multiple sclerosis (MS), the adoptive transfer of $\mathrm{CD} 8^{+} \mathrm{CD} 28^{\text {low }} \mathrm{T}$ cells from wild-type (WT) mice into recipients lacking CD8 significantly suppress disease severity, unlike CD8 ${ }^{+} \mathrm{CD} 28^{\text {high }}$ cells. This finding was supported in vitro where $\mathrm{CD} 8^{+} \mathrm{CD} 28^{\text {low }}$ T cells reduced interferon-gamma (IFN- $\gamma$ ) production from myelin oligodendrocyte glycoprotein (MOG) (MS autoantigen)specific $\mathrm{CD}^{+} \mathrm{T}$ cells and rendered APCs tolerogenic by downregulating CD40, CD80 and CD86 [53]. In EAE mice treated with a trichosanthin-derived peptide, $\mathrm{CD} 8^{+} \mathrm{CD} 28^{\text {low }}$ Tregs producing IL-10 also reduced the clinical score [54]. In MS and type 1 diabetes (T1D) patients, the frequency of $\mathrm{CD} 8^{+} \mathrm{CD} 28^{-}$Tregs is reduced compared with healthy individuals [32].

$\mathrm{T}$ cell vaccination models further demonstrate that $\mathrm{CD}^{+} \mathrm{T}$ cell suppressor function exerts a profound effect on controlling the onset of autoimmunity. For example, the adoptive transfer of $\mathrm{T}$ cells, in particular $\mathrm{CD} 8^{+}$from vaccinated mice, prevents overt EAE, owing to suppressor properties in the $\mathrm{CD}^{+} \mathrm{T}$ cell compartment [55]. This is confirmed in MS patients, in whom $\mathrm{CD}^{+}$Tregs inhibit proliferation and lyse vaccine $\mathrm{CD} 4^{+} \mathrm{T}$ cells clones in vitro [56]. A subsequent study showed that, in $\mathrm{CD}^{+}{ }^{+}$-cell-vaccinated mice, $\mathrm{V} \beta 8$-specific Qa-1-restricted $\mathrm{CD}^{+} \mathrm{T}$ cells are induced alongside activated $\mathrm{CD} 4^{+} \mathrm{V} \beta 8^{+} \mathrm{T}$ cells and lyse Qa-1 and murine TCR V $\beta 8^{+}$cells, with a similar finding in mice vaccinated with autoantigen myelin basic protein (MBP) [57].

\subsection{Rheumatoid Arthritis (RA)}

In 2005, Davila and colleagues presented a study exploring a $\mathrm{CD}^{+} \mathrm{T}$ cell-based immunotherapy strategy in RA by adoptively transferring $\mathrm{CD} 8^{+} \mathrm{CD} 28^{-} \mathrm{CD}^{-} 6^{+} \mathrm{T}$ cell clones 
from RA synovium in NOD-SCID mice engrafted with synovial tissue that suppressed T cell infiltration, IFN- $\gamma$ and TNF- $\alpha$ levels [58].

In RA patients, impaired Treg function highlights the importance of harnessing Tregs as a therapeutic tool. We have shown that $\mathrm{CD} 8^{+} \mathrm{CD} 28^{-}$Tregs are significantly increased numerically in the peripheral blood (PB) of RA patients treated with methotrexate (RA(MTX)) but exert reduced suppressor function compared to healthy individuals [33]. In patients treated with TNF inhibitors (TNFi), suppressive potential was partially restored demonstrating the impact of therapy on Treg function. Phenotypic analysis of RA(MTX) CD8 ${ }^{+} \mathrm{CD} 28^{-}$ Tregs revealed that the cells expressed low levels of ICOS and PD-1 compared with healthy individuals. Although the cells present in the synovial fluid (SF) and PB express IL-10 and mediate suppression partially by TGF- $\beta 1$, deficits in both the CD $8^{+} \mathrm{CD} 28^{-}$Treg, and the responsiveness of the target cells to suppression, hinder their full suppressive potential [33]. The increase we observed in the PB of RA patients was confirmed by Thompson and colleagues, who also showed that the expansion of $\mathrm{CD} 8^{+} \mathrm{CD} 28^{-}$Treg occurs early in the disease, correlated with disease duration and was associated with previous cytomegalovirus (CMV) infection [59].

In addition to $\mathrm{CD} 8^{+} \mathrm{CD} 28^{-}$Tregs, an anti-CD3 monoclonal antibody (mAb) has been shown to activate peripheral blood mononuclear cells (PBMC) from RA patients to induce $\mathrm{CD}^{+} \mathrm{Foxp}^{+}$Tregs that inhibit IL-17 production [22]. In RA, the induction of these cells was regulated by $\mathrm{p} 38$ phosphorylation in co-cultures of naïve $\mathrm{CD} 8^{+} \mathrm{T}$ cells in response to membrane-bound TNF- $\alpha$ and CD86 expressed on monocytes [22]. In a recent report, the assessment of SF of a subset of arthritis patients reduced TCR- $\zeta$ in CD $8{ }^{+} \mathrm{CD} 28^{\text {null }}$ expansion, which correlates with increased inflammation and neutrophil migration. Similarly, low levels of ZAP-70 in expanded CD8 ${ }^{+} \mathrm{CD} 28^{\text {low }}$ was associated with Disease Activity Score 28 (DAS28). The predominance of downregulating TCR- $\zeta$ in SF CD $8^{+} \mathrm{CD} 28^{\text {null }}$ cells in patients with seronegative arthritides suggests that TCR molecules in $\mathrm{CD} 8^{+} \mathrm{CD} 28^{-}$cells may serve as a biomarker in RA [60].

\subsection{Systemic Lupus Erythematosus (SLE)}

In the murine lupus strain, New Zealand Black/New Zealand White F1, female mice treated with an artificial synthetic peptide (pConsensus) containing MHC class I and II determinants in the $\mathrm{VH}$ of an anti-DNA Ig, displayed increased $\mathrm{CD}^{+}$Tregs $\left(\mathrm{CD} 28^{+}\right.$and $\mathrm{CD}^{-} 8^{-}$). These cells suppressed anti-DNA Ab production [61] and T cell proliferation [62] in a Foxp3- and TGF- $\beta 1$-dependent manner [61]. Furthermore, CD8 ${ }^{+}$Treg function was impaired in mice treated with pConsensus peptide in the presence of PD-1 blockade, indicating that NCRs were important for their function [63].

Two human studies have shown conflicting observations for $\mathrm{CD} 8^{+} \mathrm{CD} 28^{-}$Treg detection in SLE patients. The first showed that $\mathrm{CD} 8^{+} \mathrm{CD} 28^{-} \mathrm{T}$ cells are reduced in the $\mathrm{PB}$ of SLE patients compared to healthy or disease controls; this observation together with low levels of IL-10 and TGFB1 mRNA levels may account for defective suppressor function in disease [31]. In contrast, a second study reported a significant increase in the absolute number and percentage of $\mathrm{CD} 8^{-} \mathrm{CD} 28^{-} \mathrm{T}$ cells in SLE patients compared to healthy individuals, which positively correlated with SLEDAI (SLE disease activity index). Furthemore, in patients with active lupus nephritis, a positive correlation between $\mathrm{CD} 8^{+} \mathrm{CD} 28^{-} \mathrm{T}$ cell number expressing low levels of Foxp3 and disease activity was noted [64]. Hence, in SLE patients, the potent pro-inflammatory environment may hinder suppressor function.

\subsection{Diabetes}

In type 1 diabetic patients, treatment with an anti-CD3 $\mathrm{mAb}$ has been shown to induce $\mathrm{CD} 8^{+} \mathrm{CD} 25^{+}$Tregs, which express cytotoxic T-lymphocyte-associated protein (CTLA-4) and Foxp3 to facilitate the inhibition of $\mathrm{CD} 4^{+} \mathrm{T}$ cells in response to therapy [65]. A recent study addressing how $\mathrm{CD}^{+}$Tregs may mediate suppression in diabetes reported that intestinal levels of Ruminococcus positively correlated with the number of CD8 ${ }^{+}$Tregs in the PB [66]. 


\subsection{Systemic Sclerosis (SSc)}

In patients with systemic sclerosis (SSc), $\mathrm{CD} 8^{+} \mathrm{CD} 28^{-} \mathrm{T}$ cells are increased in the blood and skin with suppressor and cytotoxic function respectively $[67,68]$. In the skin, resident $\mathrm{CD}^{+} \mathrm{CD} 28^{-} \mathrm{T}$ cells are highly profibrotic, suggesting that suppressor potential is dependent on the microenvironment. In vitro assessment of non-antigen specific CD8 ${ }^{+} \mathrm{CD} 28^{-}$ Tregs from SSc patients further confirmed their impaired ability to suppress antigen-specific $\mathrm{CD}^{+} \mathrm{T}$ cell proliferation [9].

\section{7. $\mathrm{CD}^{+} \mathrm{CD}^{-} 8^{-}$Tregs in Gastrointestinal Disease}

$\mathrm{CD}^{+}$Tregs play a critical role in mucosal tolerance. Adoptive transfer of naïve $\mathrm{CD} 4^{+} \mathrm{CD} 45 \mathrm{RB}^{\text {high }} \mathrm{T}$ cells (colitogenic) with splenic $\mathrm{CD} 8^{+} \mathrm{CD} 28^{\text {low }} \mathrm{T}$ cells into syngeneic immunodeficient Recombinase Activating Gene-2 (RAG-2) mutant mice, prevent IBD onset via IL-10 production. Notably, the authors showed that $\mathrm{CD} 8^{+} \mathrm{CD} 28^{\mathrm{low}} \mathrm{T}$ cells isolated from the intestinal epithelium and lamina propria (LP) also had a similar protective effect mediated by IL-10 production and the responsiveness of colitogenic T cells to TGF- $\beta 1$ [69].

In a model of experimental colitis, the autoimmune regulator (AIRE)-deficient $\mathrm{CD} 8{ }^{+} \mathrm{CD} 28^{\text {low }}$ Treg suppressor function was impaired compared to WT [70]. Furthermore, in mice intranasally injected with ovalbumin (OVA) encased in oligomannose-coated liposomes, a model of food allergy, induced $\mathrm{CD} 8^{+} \mathrm{CD} 28^{\text {low }}$ Tregs and $\mathrm{CD} 4^{+} \mathrm{CD} 25^{+} \mathrm{Foxp} 3^{+}$ Tregs in the mesenteric lymph node reduced allergic diarrhea [71]. In a rat model of trinitrobenzenesulfonic acid-induced colitis, treatment with mesalazine, a therapy for ulcerative colitis (UC), increased the ratio of $\mathrm{CD} 8^{+} \mathrm{CD} 28^{+} / \mathrm{CD} 8^{+} \mathrm{CD} 28^{-} \mathrm{T}$ cells in the blood. In the colon, a reduction in $\mathrm{CD} 8^{+} \mathrm{CD} 28^{-} \mathrm{T}$ cells contributed to disease progression [72]. In human studies, the $\mathrm{CD} 8^{+} \mathrm{CD} 28^{+} / \mathrm{CD} 8^{+} \mathrm{CD} 28^{-} \mathrm{T}$ cell ratio of $<1.03$ in the $\mathrm{PB}$ acts as a prognostic tool in Crohn's disease (CD) patients progressing to an active disease stage [73]. In UC patients, a shift in the cell balance in favor of $\mathrm{CD} 8^{+} \mathrm{CD} 28^{+} \mathrm{T}$ cells in the $\mathrm{PB}$ and colon tissue is desirable [30].

In patients with inflammatory bowel disease (IBD), the frequency of LP CD8 ${ }^{+}$Tregs expressing TCRV $\beta 5.1$ are reduced compared with non-IBD inflammatory and normal LP. In vitro, $\mathrm{LP} \mathrm{CD}^{+} \mathrm{T}$ cells $\left(\mathrm{CD} 28^{+}\right.$and $\left.\mathrm{CD} 28^{-}\right)$from patients with $\mathrm{UC}$ or $\mathrm{CD}$ fail to suppress Ig production by PBMC treated with pokeweed mitogen compared with normal LP [74].

Human intestinal epithelial cells (IECs) can induce the proliferation of $\mathrm{CD} 8^{+} \mathrm{CD} 28^{-}$, $\mathrm{CD}^{+} \mathrm{CD} 28^{+}$and $\mathrm{CD} 8{ }^{+} \mathrm{CD} 28^{-} \mathrm{CD} 101^{+} \mathrm{CD} 103^{+} \mathrm{T}$ cells in the presence of gp180, a 180-kDa epithelial membrane glycoprotein. In the presence of IL-7 and IL-15, IEC-stimulated CD8 ${ }^{+}$ $\mathrm{T}$ cells are rendered suppressive, especially when assessing the $\mathrm{CD} 101^{+} \mathrm{CD} 103^{+}$population. The authors showed that suppression mediated by $\mathrm{CD} 8^{+} \mathrm{CD} 28^{-} \mathrm{CD} 101^{+} \mathrm{CD} 103^{+} \mathrm{T}$ cells required direct contact with gp180 [46] recognized by CD1d. Hence, a possible explanation for impaired regulatory function may be low or altered gp180 expression by IEC in UC, CD or IBD patients [75].

\section{Viral Infections}

$\mathrm{CD} 8^{+}$Tregs have been documented in numerous viral infections. In individuals infected with hepatitis B virus (HBV), an increase in $\mathrm{CD} 8^{+} \mathrm{CD} 28^{-} \mathrm{T}$ cells in the chronic phase of infection negatively correlates with alanine aminotransaminase (ALT) and aspartate aminotransferase (AST) levels, suggesting improved liver health [76]. In human immunodeficiency virus (HIV) infected patients, an expansion in $\mathrm{CD} 8^{+} \mathrm{CD} 28^{-} \mathrm{T}$ cells has been reported in the blood and lung [77]. Similarly, these cells are additionally expanded in the blood of RA patients with Epstein-Barr Virus (EBV) infection [78].

\section{Transplantation}

There is now increasing evidence that the interplay between co-inhibitory and costimulatory molecules plays a role in $\mathrm{CD} 8^{+} \mathrm{CD} 28^{-}$Treg function. In transplantation studies, $\mathrm{CD}^{+} \mathrm{T}$ cells from $\mathrm{B} 6$ recipients of BALB/c heart allografts undergoing anti-ICOS $\mathrm{Ab}$ treatment prolong allograft survival, unlike $\mathrm{CD} 8^{+} \mathrm{T}$ cells isolated from control mice [18]. 


\section{Cancer}

Increasing evidence points towards $\mathrm{CD} 4{ }^{+} \mathrm{CD} 25^{+} \mathrm{Foxp}^{+}$Tregs having a pathogenic role in cancer development and metastasis, primarily through inhibiting host cancer-associatedantigen adaptive immunity $[79,80]$. As the numerically dominant Treg population in the tumor microenvironment (TME), $\mathrm{CD} 4^{+} \mathrm{CD} 25^{+} \mathrm{Foxp}^{+}$cells have been extensively studied in cancers, unlike $\mathrm{CD} 8^{+} \mathrm{CD} 28^{-}$Tregs. However, the few studies there are suggest similarities between the two populations. For example, an increase in $\mathrm{CD} 8^{+} \mathrm{CD} 28^{-}$Tregs has been seen to correlate with poor prognosis in metastatic cancer patients receiving T-lymphocyte immunotherapy following chemotherapy [81], and the expression of CD39 on CD8 ${ }^{+}$Tregs has been linked to the evasion of the antitumor immune response [82].

Inhibiting the impact of $\mathrm{CD}^{+} \mathrm{CD} 25^{+}$Foxp3 ${ }^{+}$Tregs through checkpoint blockade (CTLA4 and PD-L1;PD-1) has led to significant therapeutic breakthroughs in solid cancers [83]. Work is ongoing to try to deplete these cells, e.g., through CTLA-4 targeting, or inhibit their generation, e.g., by inhibiting TGF- $\beta 1$ signaling $[80,84]$. These concepts can equally be applied to CD8 ${ }^{+} \mathrm{CD} 28^{-}$Tregs; indeed, with CTLA-4 being reported on these cells [65], some of these current therapies may already be impacting this population.

The downregulation/loss of CD28 expression on the surface of $\mathrm{CD}^{+} \mathrm{T}$ cells has been shown to coincide with normal aging [14]. Senescent $\mathrm{CD} 8^{+} \mathrm{CD} 28^{-} \mathrm{T}$ cells are oligoclonal and express NK-associated molecules CD56, CD57 and CD94 [85,86]. In cancer, wherein senescent cells impact the immune response, further studies are warranted to examine the anergic, activation and exhausted phenotype compared to $\mathrm{CD} 8^{+} \mathrm{CD} 28^{-}$Tregs.

\section{Adoptive Cell Therapy}

Cell therapies such as engineered T cells expressing a specific chimeric antigen receptor (CAR) are efficacious as a non-solid cancer immunotherapy. A recent study wherein HLA-A ${ }^{*} 02$ antigen-specific antibody (A2-CAR) human CD8 ${ }^{+}$Tregs reduced mismatched HLA-A*02 skin graft rejection and prevented xenogeneic GvHD in NSG mice [87] presents a novel platform for $\mathrm{CD}^{+}$Treg therapy.

\section{Concluding Remarks}

In conclusion, this review highlights the importance of $\mathrm{CD} 8^{+} \mathrm{CD} 28^{-}$Tregs in facilitating immune tolerance in inflammatory conditions. $\mathrm{CD} 8^{+} \mathrm{CD} 28^{-}$Tregs display functional plasticity in accordance with their microenvironment (e.g., elevated, but defective, in active RA but protective in IBD), suggesting that the targeting or use of these cells will be highly specific for each disease indication. Indeed further knowledge regarding the factors that govern functionality may lead to therapies that modulate the impact of these cells in situ. Further to this, the field urgently requires consensus with regards to markers that are indicative of regulatory function, rather than the umbrella term of $\mathrm{CD}^{+} \mathrm{CD} 28^{-}$, which, as discussed, includes well-established inflammatory populations.

If a bona fide functional marker is found, not only could it be used to potentially deplete these cells in pathologies such as cancers, but also, pending robust large-scale expansion methodologies, it could be used to establish an anti-inflammatory adoptive cellular therapeutic for use in patients in whom current treatment is ineffective.

Author Contributions: Writing-original manuscript preparation, S.C.; writing-review and editing, R.B., S.C., C.R.T., E.H.C. All authors have read and agreed to the published version of the manuscript.

Funding: R.B. is funded by the Medical Research Council (MRC) (MR/R000026/1). E.H.C. is funded by Versus Arthritis (20016) and Health and Care Research Wales (DSCHR).

Conflicts of Interest: The authors declare no conflict of interest. 


\section{References}

1. Cantor, H.; Shen, F.W.; Boyse, E.A. Separation of helper T cells from suppressor T cells expressing different Ly components. II. Activation by antigen: After immunization, antigen-specific suppressor and helper activities are mediated by distinct T-cell subclasses. J. Exp. Med. 1976, 143, 1391. [CrossRef]

2. Jandinski, J.; Cantor, H.; Tadakuma, T.; Peavy, D.L.; Pierce, C.W. Separation of helper T cells from suppressor T cells expressing different Ly components. I. Polyclonal activation: Suppressor and helper activities are inherent properties of distinct T-cell subclasses. J. Exp. Med. 1976, 143, 1382-1390. [CrossRef] [PubMed]

3. Fontenot, J.D.; Gavin, M.A.; Rudensky, A.Y. Foxp3 programs the development and function of CD4 $4^{+} \mathrm{CD} 25^{+}$regulatory T cells. Nat. Immunol. 2003, 4, 330-336. [CrossRef]

4. Hori, S.; Nomura, T.; Sakaguchi, S. Control of regulatory T cell development by the transcription factor Foxp3. Science 2003, 299, 1057-1061. [CrossRef]

5. Khattri, R.; Cox, T.; Yasayko, S.A.; Ramsdell, F. An essential role for Scurfin in CD4 $4^{+} \mathrm{CD} 25^{+}$T regulatory cells. Nat. Immunol. 2003, 4, 337-342. [CrossRef]

6. $\quad$ Bennett, C.L.; Christie, J.; Ramsdell, F.; Brunkow, M.E.; Ferguson, P.J.; Whitesell, L.; Kelly, T.E.; Saulsbury, F.T.; Chance, P.F.; Ochs, H.D. The immune dysregulation, polyendocrinopathy, enteropathy, X-linked syndrome (IPEX) is caused by mutations of FOXP3. Nat. Genet. 2001, 27, 20-21. [CrossRef] [PubMed]

7. Powell, B.R.; Buist, N.R.; Stenzel, P. An X-linked syndrome of diarrhea, polyendocrinopathy, and fatal infection in infancy. J. Pediatr. 1982, 100, 731-737. [CrossRef]

8. Mahic, M.; Henjum, K.; Yaqub, S.; Bjornbeth, B.A.; Torgersen, K.M.; Tasken, K.; Aandahl, E.M. Generation of highly suppressive adaptive CD8(+)CD25(+)FOXP3(+) regulatory T cells by continuous antigen stimulation. Eur. J. Immunol. 2008, 38, 640-646. [CrossRef]

9. Filaci, G.; Fravega, M.; Negrini, S.; Procopio, F.; Fenoglio, D.; Rizzi, M.; Brenci, S.; Contini, P.; Olive, D.; Ghio, M.; et al. Nonantigen specific $\mathrm{CD}^{+} \mathrm{T}$ suppressor lymphocytes originate from $\mathrm{CD} 8^{+} \mathrm{CD} 28^{-} \mathrm{T}$ cells and inhibit both T-cell proliferation and CTL function. Hum. Immunol. 2004, 65, 142-156. [CrossRef] [PubMed]

10. Poggi, A.; Zocchi, M.R. Role of bone marrow stromal cells in the generation of human CD8 ${ }^{+}$regulatory T cells. Hum. Immunol. 2008, 69, 755-759. [CrossRef]

11. Niederlova, V.; Tsyklauri, O.; Chadimova, T.; Stepanek, O. CD8(+) Tregs revisited: A heterogeneous population with different phenotypes and properties. Eur. J. Immunol. 2021, 51, 512-530. [CrossRef]

12. Shao, L.; Jacobs, A.R.; Johnson, V.V.; Mayer, L. Activation of $\mathrm{CD}^{+}$regulatory T cells by human placental trophoblasts. J. Immunol. 2005, 174, 7539-7547. [CrossRef]

13. Sugita, S.; Futagami, Y.; Horie, S.; Mochizuki, M. Transforming growth factor beta-producing Foxp3(+)CD8(+)CD25(+) T cells induced by iris pigment epithelial cells display regulatory phenotype and acquire regulatory functions. Exp. Eye Res. 2007, 85, 626-636. [CrossRef]

14. Fagnoni, F.F.; Vescovini, R.; Mazzola, M.; Bologna, G.; Nigro, E.; Lavagetto, G.; Franceschi, C.; Passeri, M.; Sansoni, P. Expansion of cytotoxic CD8 ${ }^{+} \mathrm{CD} 28^{-}$T cells in healthy ageing people, including centenarians. Immunology 1996, 88, 501-507. [CrossRef]

15. Parish, S.T.; Wu, J.E.; Effros, R.B. Modulation of T lymphocyte replicative senescence via TNF-\{alpha\} inhibition: Role of caspase-3. J. Immunol. 2009, 182, 4237-4243. [CrossRef]

16. Dai, H.; Wan, N.; Zhang, S.; Moore, Y.; Wan, F.; Dai, Z. Cutting edge: Programmed death- 1 defines CD8 ${ }^{+}$CD122 ${ }^{+}$T cells as regulatory versus memory T cells. J. Immunol. 2010, 185, 803-807. [CrossRef]

17. Rifa'i, M.; Shi, Z.; Zhang, S.Y.; Lee, Y.H.; Shiku, H.; Isobe, K.; Suzuki, H. CD8 ${ }^{+}$CD122 $2^{+}$regulatory T cells recognize activated T cells via conventional MHC class I-alphabetaTCR interaction and become IL-10-producing active regulatory cells. Int. Immunol. 2008, 20, 937-947. [CrossRef]

18. Izawa, A.; Yamaura, K.; Albin, M.J.; Jurewicz, M.; Tanaka, K.; Clarkson, M.R.; Ueno, T.; Habicht, A.; Freeman, G.J.; Yagita, H.; et al. A novel alloantigen-specific $\mathrm{CD} 8^{+} \mathrm{PD}^{+}$regulatory $\mathrm{T}$ cell induced by ICOS-B7h blockade in vivo. J. Immunol. 2007, 179, 786-796. [CrossRef]

19. Villarreal, D.O.; Allegrezza, M.J.; Smith, M.A.; Chin, D.; Luistro, L.L.; Snyder, L.A. Targeting of CD122 enhances antitumor immunity by altering the tumor immune environment. Oncotarget 2017, 8, 109151-109160. [CrossRef]

20. Motegi, A.; Kinoshita, M.; Inatsu, A.; Habu, Y.; Saitoh, D.; Seki, S. IL-15-induced CD ${ }^{+}$CD $122^{+}$T cells increase antibacterial and anti-tumor immune responses: Implications for immune function in aged mice. J. Leukoc. Biol. 2008, 84, 1047-1056. [CrossRef]

21. Suzuki, H.; Shi, Z.; Okuno, Y.; Isobe, K. Are CD8 ${ }^{+} \mathrm{CD} 122^{+}$cells regulatory T cells or memory T cells? Hum. Immunol. 2008, 69, 751-754. [CrossRef]

22. Ellis, S.D.; McGovern, J.L.; van Maurik, A.; Howe, D.; Ehrenstein, M.R.; Notley, C.A. Induced CD8 ${ }^{+}$Foxp3 ${ }^{+}$Treg cells in rheumatoid arthritis are modulated by 38 phosphorylation and monocytes expressing membrane tumor necrosis factor alpha and CD86. Arthritis Rheumatol. 2014, 66, 2694-2705. [CrossRef]

23. Zhang, L.; Bertucci, A.M.; Ramsey-Goldman, R.; Burt, R.K.; Datta, S.K. Regulatory T cell (Treg) subsets return in patients with refractory lupus following stem cell transplantation, and TGF-beta-producing CD8 ${ }^{+}$Treg cells are associated with immunological remission of lupus. J. Immunol. 2009, 183, 6346-6358. [CrossRef] 
24. Popescu, I.; Macedo, C.; Abu-Elmagd, K.; Shapiro, R.; Hua, Y.; Thomson, A.W.; Morelli, A.E.; Storkus, W.J.; Metes, D. EBV-specific $\mathrm{CD}^{+} \mathrm{T}$ cell reactivation in transplant patients results in expansion of $\mathrm{CD} 8^{+}$type- 1 regulatory T cells. Am. J. Transpl. 2007, 7, 1215-1223. [CrossRef]

25. Kiniwa, Y.; Miyahara, Y.; Wang, H.Y.; Peng, W.; Peng, G.; Wheeler, T.M.; Thompson, T.C.; Old, L.J.; Wang, R.F. CD8 ${ }^{+}$Foxp3 ${ }^{+}$ regulatory T cells mediate immunosuppression in prostate cancer. Clin. Cancer Res. 2007, 13, 6947-6958. [CrossRef]

26. Avivi, I.; Stroopinsky, D.; Rowe, J.M.; Katz, T. A subset of CD8 ${ }^{+} \mathrm{T}$ cells acquiring selective suppressive properties may play a role in GvHD management. Transpl. Immunol. 2013, 28, 57-61. [CrossRef]

27. Sharabi, A.; Mozes, E. The suppression of murine lupus by a tolerogenic peptide involves foxp3-expressing CD8 cells that are required for the optimal induction and function of foxp3-expressing CD4 cells. J. Immunol. 2008, 181, 3243-3251. [CrossRef] [PubMed]

28. Robb, R.J.; Lineburg, K.E.; Kuns, R.D.; Wilson, Y.A.; Raffelt, N.C.; Olver, S.D.; Varelias, A.; Alexander, K.A.; Teal, B.E.; Sparwasser, $\mathrm{T}$; ; et al. Identification and expansion of highly suppressive CD8(+)FoxP3(+) regulatory $\mathrm{T}$ cells after experimental allogeneic bone marrow transplantation. Blood 2012, 119, 5898-5908. [CrossRef]

29. Zimmerer, J.M.; Ringwald, B.A.; Elzein, S.M.; Avila, C.L.; Warren, R.T.; Abdel-Rasoul, M.; Bumgardner, G.L. Antibody-suppressor $\mathrm{CD}^{+}$T Cells Require CXCR5. Transplantation 2019, 103, 1809-1820. [CrossRef] [PubMed]

30. Dai, S.X.; Wu, G.; Zou, Y.; Feng, Y.L.; Liu, H.B.; Feng, J.S.; Chi, H.G.; Lv, R.X.; Zheng, X.B. Balance of CD8 ${ }^{+}$CD28 $8^{+} / C D 8^{+}$CD28 ${ }^{-}$ T lymphocytes is vital for patients with ulcerative colitis. Dig. Dis. Sci. 2013, 58, 88-96. [CrossRef]

31. Tulunay, A.; Yavuz, S.; Direskeneli, H.; Eksioglu-Demiralp, E. CD8 ${ }^{+} \mathrm{CD} 28^{-}$, suppressive T cells in systemic lupus erythematosus. Lupus 2008, 17, 630-637. [CrossRef] [PubMed]

32. Mikulkova, Z.; Praksova, P.; Stourac, P.; Bednarik, J.; Strajtova, L.; Pacasova, R.; Belobradkova, J.; Dite, P.; Michalek, J. Numerical defects in $\mathrm{CD}^{+} \mathrm{CD} 28^{-}$T-suppressor lymphocyte population in patients with type 1 diabetes mellitus and multiple sclerosis. Cell Immunol. 2010, 262, 75-79. [CrossRef] [PubMed]

33. Ceeraz, S.; Hall, C.; Choy, E.H.; Spencer, J.; Corrigall, V.M. Defective CD8 ${ }^{+} \mathrm{CD} 28^{+}$regulatory T cell suppressor function in rheumatoid arthritis is restored by tumour necrosis factor inhibitor therapy. Clin. Exp. Immunol. 2013, 174, 18-26. [CrossRef]

34. Jiang, H.; Chess, L. The specific regulation of immune responses by CD8 ${ }^{+} \mathrm{T}$ cells restricted by the MHC class Ib molecule, Qa-1. Annu. Rev. Immunol. 2000, 18, 185-216. [CrossRef] [PubMed]

35. Kim, H.J.; Verbinnen, B.; Tang, X.; Lu, L.; Cantor, H. Inhibition of follicular T-helper cells by CD8(+) regulatory T cells is essential for self tolerance. Nature 2010, 467, 328-332. [CrossRef]

36. Clement, M.; Guedj, K.; Andreata, F.; Morvan, M.; Bey, L.; Khallou-Laschet, J.; Gaston, A.T.; Delbosc, S.; Alsac, J.M.; Bruneval, P.; et al. Control of the $\mathrm{T}$ follicular helper-germinal center B-cell axis by CD8(+) regulatory $\mathrm{T}$ cells limits atherosclerosis and tertiary lymphoid organ development. Circulation 2015, 131, 560-570. [CrossRef]

37. Liu, H.; Wang, Y.; Zeng, Q.; Zeng, Y.Q.; Liang, C.L.; Qiu, F.; Nie, H.; Dai, Z. Suppression of allograft rejection by CD8 ${ }^{+}$CD122 ${ }^{+}$PD$1^{+}$Tregs is dictated by their Fas ligand-initiated killing of effector T cells versus Fas-mediated own apoptosis. Oncotarget 2017, 8, 24187-24195. [CrossRef]

38. Horwitz, D.A.; Pan, S.; Ou, J.N.; Wang, J.; Chen, M.; Gray, J.D.; Zheng, S.G. Therapeutic polyclonal human CD8 ${ }^{+}$CD25 $5^{+}$Fox3 ${ }^{+}$ TNFR2 ${ }^{+}$PD-L1 ${ }^{+}$regulatory cells induced ex-vivo. Clin. Immunol. 2013, 149, 450-463. [CrossRef]

39. Taghavie-Moghadam, P.L.; Waseem, T.C.; Hattler, J.; Glenn, L.M.; Dobrian, A.D.; Kaplan, M.H.; Yang, Y.; Nurieva, R.; Nadler, J.L.; Galkina, E.V. STAT4 Regulates the CD8(+) Regulatory T Cell/T Follicular Helper Cell Axis and Promotes Atherogenesis in Insulin-Resistant Ldlr(-/-) Mice. J. Immunol. 2017, 199, 3453-3465. [CrossRef] [PubMed]

40. Chen, Y.; Yu, M.; Zheng, Y.; Fu, G.; Xin, G.; Zhu, W.; Luo, L.; Burns, R.; Li, Q.Z.; Dent, A.L.; et al. CXCR5(+)PD-1(+) follicular helper CD8 T cells control B cell tolerance. Nat. Commun. 2019, 10, 4415. [CrossRef]

41. Simone, R.; Zicca, A.; Saverino, D. The frequency of regulatory CD3+CD8 ${ }^{+} \mathrm{CD} 28^{-} \mathrm{CD} 25^{+} \mathrm{T}$ lymphocytes in human peripheral blood increases with age. J. Leukoc. Biol. 2008, 84, 1454-1461. [CrossRef]

42. Filaci, G.; Fenoglio, D.; Fravega, M.; Ansaldo, G.; Borgonovo, G.; Traverso, P.; Villaggio, B.; Ferrera, A.; Kunkl, A.; Rizzi, M.; et al. $\mathrm{CD}^{+} \mathrm{CD} 28^{-} \mathrm{T}$ regulatory lymphocytes inhibiting $\mathrm{T}$ cell proliferative and cytotoxic functions infiltrate human cancers. J. Immunol. 2007, 179, 4323-4334. [CrossRef]

43. Colovai, A.I.; Mirza, M.; Vlad, G.; Wang, S.; Ho, E.; Cortesini, R.; Suciu-Foca, N. Regulatory CD8 ${ }^{+}$CD28 ${ }^{-}$T cells in heart transplant recipients. Hum. Immunol. 2003, 64, 31-37. [CrossRef]

44. Baeten, D.; Louis, S.; Braud, C.; Braudeau, C.; Ballet, C.; Moizant, F.; Pallier, A.; Giral, M.; Brouard, S.; Soulillou, J.P. Phenotypically and functionally distinct $\mathrm{CD} 8^{+}$lymphocyte populations in long-term drug-free tolerance and chronic rejection in human kidney graft recipients. J. Am. Soc. Nephrol. 2006, 17, 294-304. [CrossRef]

45. Ciubotariu, R.; Vasilescu, R.; Ho, E.; Cinti, P.; Cancedda, C.; Poli, L.; Late, M.; Liu, Z.; Berloco, P.; Cortesini, R.; et al. Detection of T suppressor cells in patients with organ allografts. Hum. Immunol. 2001, 62, 15-20. [CrossRef]

46. Allez, M.; Brimnes, J.; Dotan, I.; Mayer, L. Expansion of CD8 ${ }^{+} \mathrm{T}$ cells with regulatory function after interaction with intestinal epithelial cells. Gastroenterology 2002, 123, 1516-1526. [CrossRef] [PubMed]

47. Ciubotariu, R.; Colovai, A.I.; Pennesi, G.; Liu, Z.; Smith, D.; Berlocco, P.; Cortesini, R.; Suciu-Foca, N. Specific suppression of human $\mathrm{CD}^{+}$Th cell responses to pig MHC antigens by CD8 ${ }^{+} \mathrm{CD} 28^{-}$regulatory T cells. J. Immunol. 1998, 161, 5193-5202.

48. Jiang, S.; Tugulea, S.; Pennesi, G.; Liu, Z.; Mulder, A.; Lederman, S.; Harris, P.; Cortesini, R.; Suciu-Foca, N. Induction of MHC-class I restricted human suppressor T cells by peptide priming in vitro. Hum. Immunol. 1998, 59, 690-699. [CrossRef] 
49. Scotto, L.; Naiyer, A.J.; Galluzzo, S.; Rossi, P.; Manavalan, J.S.; Kim-Schulze, S.; Fang, J.; Favera, R.D.; Cortesini, R.; Suciu-Foca, N. Overlap between molecular markers expressed by naturally occurring $\mathrm{CD} 4{ }^{+} \mathrm{CD} 25^{+}$regulatory $\mathrm{T}$ cells and antigen specific $\mathrm{CD}^{+} \mathrm{CD} 25^{+}$and $\mathrm{CD} 8^{+} \mathrm{CD} 28^{-}$T suppressor cells. Hum. Immunol. 2004, 65, 1297-1306. [CrossRef] [PubMed]

50. Li, J.; Liu, Z.; Jiang, S.; Cortesini, R.; Lederman, S.; Suciu-Foca, N. T suppressor lymphocytes inhibit NF-kappa B-mediated transcription of CD86 gene in APC. J. Immunol. 1999, 163, 6386-6392.

51. Manavalan, J.S.; Kim-Schulze, S.; Scotto, L.; Naiyer, A.J.; Vlad, G.; Colombo, P.C.; Marboe, C.; Mancini, D.; Cortesini, R.; Suciu-Foca, N. Alloantigen specific CD8 ${ }^{+} \mathrm{CD} 28^{-}$Foxp3 $^{+} \mathrm{T}$ suppressor cells induce ILT3 ${ }^{+} \mathrm{ILT}^{+}$tolerogenic endothelial cells, inhibiting alloreactivity. Int. Immunol. 2004, 16, 1055-1068. [CrossRef]

52. Yu, Y.; Zitzner, J.R.; Houlihan, J.; Herrera, N.; Xu, L.; Miller, J.; Mathew, J.M.; Tambur, A.R.; Luo, X. Common gamma chain cytokines promote rapid in vitro expansion of allo-specific human CD8 ${ }^{+}$suppressor T cells. PLoS ONE 2011, 6, e28948. [CrossRef]

53. Najafian, N.; Chitnis, T.; Salama, A.D.; Zhu, B.; Benou, C.; Yuan, X.; Clarkson, M.R.; Sayegh, M.H.; Khoury, S.J. Regulatory functions of $\mathrm{CD} 8^{+} \mathrm{CD} 28^{-} \mathrm{T}$ cells in an autoimmune disease model. J. Clin. Invest. 2003, 112, 1037-1048. [CrossRef]

54. Yang, N.; Li, Z.; Jiao, Z.; Gu, P.; Zhou, Y.; Lu, L.; Chou, K.Y. A Trichosanthin-derived peptide suppresses type 1 immune responses by TLR2-dependent activation of CD8(+)CD28(-) Tregs. Clin. Immunol. 2014, 153, 277-287. [CrossRef]

55. Sun, D.; Qin, Y.; Chluba, J.; Epplen, J.T.; Wekerle, H. Suppression of experimentally induced autoimmune encephalomyelitis by cytolytic T-T cell interactions. Nature 1988, 332, 843-845. [CrossRef]

56. Zhang, J.; Medaer, R.; Stinissen, P.; Hafler, D.; Raus, J. MHC-restricted depletion of human myelin basic protein-reactive T cells by T cell vaccination. Science 1993, 261, 1451-1454. [CrossRef]

57. Jiang, H.; Kashleva, H.; Xu, L.X.; Forman, J.; Flaherty, L.; Pernis, B.; Braunstein, N.S.; Chess, L. T cell vaccination induces T cell receptor Vbeta-specific Qa-1-restricted regulatory CD8(+) T cells. Proc. Natl. Acad. Sci. USA 1998, 95, 4533-4537. [CrossRef]

58. Davila, E.; Kang, Y.M.; Park, Y.W.; Sawai, H.; He, X.; Pryshchep, S.; Goronzy, J.J.; Weyand, C.M. Cell-based immunotherapy with suppressor $\mathrm{CD}^{+} \mathrm{T}$ cells in rheumatoid arthritis. J. Immunol. 2005, 174, 7292-7301. [CrossRef]

59. Thompson, C.; Davies, R.; Williams, A.; Jones, G.; Choy, E.H.S. CD28(-) Cells Are Increased in Early Rheumatoid Arthritis and Are Linked With Cytomegalovirus Status. Front. Med. 2020, 7, 129. [CrossRef]

60. Zizzo, G.; De Santis, M.; Bosello, S.; Tolusso, B.; Alivernini, S.; De Luca, G.; Gremese, E.; Ferraccioli, G. Measuring the T-cell down-regulation of TCR-zeta, ZAP-70 and CD28 in arthritis patients: An old tool for new biomarkers. Eur. J. Immunol. 2019, 49, 2195-2203. [CrossRef]

61. Hahn, B.H.; Singh, R.P.; La Cava, A.; Ebling, F.M. Tolerogenic treatment of lupus mice with consensus peptide induces Foxp3expressing, apoptosis-resistant, TGFbeta-secreting CD8 ${ }^{+} \mathrm{T}$ cell suppressors. J. Immunol. 2005, 175, 7728-7737. [CrossRef] [PubMed]

62. Singh, R.P.; La Cava, A.; Wong, M.; Ebling, F.; Hahn, B.H. CD8 ${ }^{+}$T cell-mediated suppression of autoimmunity in a murine lupus model of peptide-induced immune tolerance depends on Foxp3 expression. J. Immunol. 2007, 178, 7649-7657. [CrossRef] [PubMed]

63. Singh, R.P.; La Cava, A.; Hahn, B.H. pConsensus peptide induces tolerogenic CD8 ${ }^{+} \mathrm{T}$ cells in lupus-prone (NZB x NZW)F1 mice by differentially regulating Foxp3 and PD1 molecules. J. Immunol. 2008, 180, 2069-2080. [CrossRef] [PubMed]

64. Zabinska, M.; Krajewska, M.; Koscielska-Kasprzak, K.; Klinger, M. CD3(+)CD8(+)CD28(-) T Lymphocytes in Patients with Lupus Nephritis. J. Immunol. Res. 2016, 2016, 1058165. [CrossRef] [PubMed]

65. Bisikirska, B.; Colgan, J.; Luban, J.; Bluestone, J.A.; Herold, K.C. TCR stimulation with modified anti-CD3 mAb expands CD8 ${ }^{+}$T cell population and induces CD8 ${ }^{+} \mathrm{CD} 25^{+}$Tregs. J. Clin. Invest. 2005, 115, 2904-2913. [CrossRef]

66. Shimokawa, C.; Kato, T.; Takeuchi, T.; Ohshima, N.; Furuki, T.; Ohtsu, Y.; Suzue, K.; Imai, T.; Obi, S.; Olia, A.; et al. CD8(+) regulatory $\mathrm{T}$ cells are critical in prevention of autoimmune-mediated diabetes. Nat. Commun. 2020, 11, 1922. [CrossRef]

67. Li, G.; Larregina, A.T.; Domsic, R.T.; Stolz, D.B.; Medsger, T.A., Jr.; Lafyatis, R.; Fuschiotti, P. Skin-Resident Effector Memory CD8(+)CD28(-) T Cells Exhibit a Profibrotic Phenotype in Patients with Systemic Sclerosis. J. Investig. Dermatol. 2017, 137, 1042-1050. [CrossRef] [PubMed]

68. Fenoglio, D.; Battaglia, F.; Parodi, A.; Stringara, S.; Negrini, S.; Panico, N.; Rizzi, M.; Kalli, F.; Conteduca, G.; Ghio, M.; et al. Alteration of Th17 and Treg cell subpopulations co-exist in patients affected with systemic sclerosis. Clin. Immunol. 2011, 139, 249-257. [CrossRef]

69. Menager-Marcq, I.; Pomie, C.; Romagnoli, P.; van Meerwijk, J.P. CD8 ${ }^{+}$CD28 ${ }^{-}$regulatory T lymphocytes prevent experimental inflammatory bowel disease in mice. Gastroenterology 2006, 131, 1775-1785. [CrossRef]

70. Pomie, C.; Vicente, R.; Vuddamalay, Y.; Lundgren, B.A.; van der Hoek, M.; Enault, G.; Kagan, J.; Fazilleau, N.; Scott, H.S.; Romagnoli, P.; et al. Autoimmune regulator (AIRE)-deficient CD8 ${ }^{+} \mathrm{CD} 28$ low regulatory $\mathrm{T}$ lymphocytes fail to control experimental colitis. Proc. Natl. Acad. Sci. USA 2011, 108, 12437-12442. [CrossRef]

71. Kawakita, A.; Shirasaki, H.; Yasutomi, M.; Tokuriki, S.; Mayumi, M.; Naiki, H.; Ohshima, Y. Immunotherapy with oligomannosecoated liposomes ameliorates allergic symptoms in a murine food allergy model. Allergy 2012, 67, 371-379. [CrossRef] [PubMed]

72. Dai, S.; Gu, H.; Lin, Q.; Xing, T.; Chen, M.; Zhong, T.; Wu, G.; Feng, Y.; Liu, H.; Gao, Y.; et al. Disequilibrium in the CD8(+)CD28(+)/CD8(+)CD28(-) T Lymphocyte Balance Is Related to Prognosis in Rats with Trinitrobenzenesulfonic AcidInduced Colitis. Dig. Dis. Sci. 2017, 62, 639-651. [CrossRef] 
73. Dai, S.X.; Gu, H.X.; Lin, Q.Y.; Wu, Y.K.; Wang, X.Y.; Huang, S.Z.; Xing, T.S.; Chen, M.H.; Zhang, Q.F.; Zheng, Z.W.; et al. Decreased $\mathrm{CD} 8^{+} \mathrm{CD} 28^{+} / \mathrm{CD}^{+} \mathrm{CD} 28^{-} \mathrm{T}$ cell ratio can sensitively predict poor outcome for patients with complicated Crohn disease. Medicine 2017, 96, e7247. [CrossRef]

74. Brimnes, J.; Allez, M.; Dotan, I.; Shao, L.; Nakazawa, A.; Mayer, L. Defects in CD8 ${ }^{+}$regulatory T cells in the lamina propria of patients with inflammatory bowel disease. J. Immunol. 2005, 174, 5814-5822. [CrossRef] [PubMed]

75. Toy, L.S.; Yio, X.Y.; Lin, A.; Honig, S.; Mayer, L. Defective expression of gp180, a novel CD8 ligand on intestinal epithelial cells, in inflammatory bowel disease. J. Clin. Investig. 1997, 100, 2062-2071. [CrossRef]

76. Shen, X.H.; Xu, P.; Yu, X.; Song, H.F.; Chen, H.; Zhang, X.G.; Wu, M.Y.; Wang, X.F. Discrepant Clinical Significance of CD28(+)CD8(-) and CD4(+)CD25(high) Regulatory T Cells During the Progression of Hepatitis B Virus Infection. Viral Immunol. 2018, 31, 548-558. [CrossRef] [PubMed]

77. Saukkonen, J.J.; Kornfeld, H.; Berman, J.S. Expansion of a CD8 ${ }^{+} \mathrm{CD} 28^{-}$cell population in the blood and lung of HIV-positive patients. J. Acquir. Immune Defic. Syndr. 1993, 6, 1194-1204.

78. Klatt, T.; Ouyang, Q.; Flad, T.; Koetter, I.; Buhring, H.J.; Kalbacher, H.; Pawelec, G.; Muller, C.A. Expansion of peripheral CD8 ${ }^{+}$ CD28- ${ }^{-}$cells in response to Epstein-Barr virus in patients with rheumatoid arthritis. J. Rheumatol. 2005, 32, $239-251$.

79. Granito, A.; Muratori, L.; Lalanne, C.; Quarneti, C.; Ferri, S.; Guidi, M.; Lenzi, M.; Muratori, P. Hepatocellular carcinoma in viral and autoimmune liver diseases: Role of $\mathrm{CD} 4{ }^{+} \mathrm{CD} 25^{+} \mathrm{Foxp}^{+}$regulatory $\mathrm{T}$ cells in the immune microenvironment. World J. Gastroenterol. 2021, 27, 2994-3009. [CrossRef]

80. Li, C.; Jiang, P.; Wei, S.; Xu, X.; Wang, J. Regulatory T cells in tumor microenvironment: New mechanisms, potential therapeutic strategies and future prospects. Mol. Cancer 2020, 19, 116. [CrossRef] [PubMed]

81. Song, Q.; Ren, J.; Zhou, X.; Wang, X.; Song, G.; Hobeika, A.; Yuan, Y.; Lyerly, H.K. Circulating CD8(+)CD28(-) suppressor T cells tied to poorer prognosis among metastatic breast cancer patients receiving adoptive T-cell therapy: A cohort study. Cytotherapy 2018, 20, 126-133. [CrossRef] [PubMed]

82. Parodi, A.; Battaglia, F.; Kalli, F.; Ferrera, F.; Conteduca, G.; Tardito, S.; Stringara, S.; Ivaldi, F.; Negrini, S.; Borgonovo, G.; et al. CD39 is highly involved in mediating the suppression activity of tumor-infiltrating $\mathrm{CD}^{+} \mathrm{T}^{+}$regulatory lymphocytes. Cancer Immunol. Immunother. 2013, 62, 851-862. [CrossRef] [PubMed]

83. Robert, C. A decade of immune-checkpoint inhibitors in cancer therapy. Nat. Commun. 2020, 11, 3801. [CrossRef]

84. Saleh, R.; Elkord, E. FoxP3(+) T regulatory cells in cancer: Prognostic biomarkers and therapeutic targets. Cancer Lett. 2020, 490, 174-185. [CrossRef] [PubMed]

85. Tarazona, R.; DelaRosa, O.; Alonso, C.; Ostos, B.; Espejo, J.; Pena, J.; Solana, R. Increased expression of NK cell markers on T lymphocytes in aging and chronic activation of the immune system reflects the accumulation of effector/senescent T cells. Mech. Ageing Dev. 2000, 121, 77-88. [CrossRef]

86. Labalette, M.; Leteurtre, E.; Thumerelle, C.; Grutzmacher, C.; Tourvieille, B.; Dessaint, J.P. Peripheral human CD8(+)CD28(+)T lymphocytes give rise to CD28(-)progeny, but IL-4 prevents loss of CD28 expression. Int. Immunol. 1999, 11, 1327-1336. [CrossRef]

87. Bezie, S.; Charreau, B.; Vimond, N.; Lasselin, J.; Gerard, N.; Nerriere-Daguin, V.; Bellier-Waast, F.; Duteille, F.; Anegon, I.; Guillonneau, C. Human CD8 ${ }^{+}$Tregs expressing a MHC-specific CAR display enhanced suppression of human skin rejection and GVHD in NSG mice. Blood Adv. 2019, 3, 3522-3538. [CrossRef] [PubMed] 